\section{Earthquakes in New Zealand}

DURING April 1942, ten strong distant earthquakes were registered on the seismographs situated in various parts of New Zealand (New Zealand Seismological Report, Provisional Bulletin No. P.122). Additionally, there were twenty earthquakes which were felt in some part of the islands during the month. The strongest were on April 25 at 4 h. $53 \cdot 2 \mathrm{~m}$. U.T., which was felt with intensity 6 on the Rossi-Forel scale in the southern Hawke's Bay and Manawatu regions, and on April 26 at $00 \mathrm{~h}$. $26 \cdot 3 \mathrm{~m}$. U.T., which was felt with intensity 5 (R.F.) in the neighbourhood of Upper Takaka. Other regions affected were Cook Strait and Christchurch, April 1, Hastings, April 2, Rotorua, April 8, Wairoa, April 18, Naseby, April 28, and Tokaanu, April 30. Minor activity was also recorded on several days at the observatories of Wellington, Christchurch, Auckland and Arapuni.

The strong New Zealand earthquake of J une 24 which occurred at about 11.18 p.m. (local time) in the neighbourhood of Masterton (NATURE, July 4, p. 18) was strongly recorded with a full suite of pulses at Kew Observatory. According to the provisional interpretation of the seismogram at Kew, the vertical record received $e P K P_{1}$ at $11 \mathrm{~h} .36 \mathrm{~m} .32 \mathrm{~s}$. U.T. on June 24. On this record a maximum ground movement at Kew of $86 \mu$ was attained at $13 \mathrm{~h} .04 \mathrm{~m}$. 15s. U.T. and the recording finished at about 17h. U.T.

\section{Electrical Equipment of Buildings}

Tre Institution of Electrical Engineers has just issued recommended War Emergency Relaxations of the Regulations for the Electrical Equipment of Buildings (11th Edition), copies of which are available from the Institution free of charge, except where a number of copies is required. Regulation No. 304 relating to voltage-drop is amended, and the current ratings of certain cables are increased. The currentrating tables affected are Nos. 5 to 9 inclusive and 16. Two new tables, 5(A) for small single-core cables of earthed concentric wiring, and $10(\mathrm{~A})$ for mineral insulated cables of $0.007 \mathrm{sq}$. in. cross-sectional area and above, are now added. Table $10(\mathrm{~A})$ takes the place of Tables 10,11 and 12 referred to in clause 302 (B) for the cables in question. The purpose of the relaxations is to economize in materials.

\section{Beit Memorial Fellowships for Medical Research}

AT a recent meeting of the Trustees of the Beit Memorial Fellowships for Medical Research, Dr. A. N. Drury, Huddersfield lecturer in special pathology in the University of Cambridge, was appointed to the Advisory Board in succession to the late Prof. A. J. Clark. The Trustees noted with pleasure the election this year of three past fellows to the fellowship of the Royal Society, namely, E. Hindle (junior fellow, 1910-12, and senior in tropical medicine, 1927-33) ; F. M. Burnet (1926-27) and A. R. Todd (1935-36). Of the twenty-eight present fellows, there are now fourteen seconded for whole-time warwork.

The following elections have been made, with permission for each fellow to be seconded at any time for war duties : 4th Year Fellowship ( $\$ 500$ a year). Mr. E. G. L. Bywaters, to continue his studies of crush injuries in relation to kidney function, at the British Postgraduate Medical School, London. Junior Fellowships (£400 a year). Dr. D. Herbert, to study the biochemistry of toxoids for active immunization against gas gangrene, at the Dunn
Biochemical Laboratory, University of Cambridge. Dr. F. W. Landgrebe, to study the separation of posterior pituitary hormones, and their clinical uses, at the Medical School, University of Aberdeen.

\section{The Night Sky in August}

THE moon is new on August 12d. 02h. 28m. U.T. and full on August 26d. $03 \mathrm{~h} .46 \mathrm{~m}$. The following conjunctions will occur during the month : Aug. 2d. 04h., Venus in conjunction with Jupiter, Venus $0.3^{\circ} \mathrm{S}$.; Aug. 6d. $09 \mathrm{~h}$., Saturn in conjunction with the moon, Saturn $3^{\circ}$ N.; Aug. 9d. 05h., Jupiter in conjunction with the moon, Jupiter $4^{\circ}$ N.; Aug. 9d. 21h., Venus in conjunction with the moon, Venus $4^{\circ}$ N. ; Aug. 13d. 15h., Mars in conjunction with the moon, Mars $0.7^{\circ}$ N. ; Aug. 19d. 13h., Mercury in conjunction with Mars, Mercury $0.01^{\circ} \mathrm{S}$. Mercury is in conjunction with the sun on Aug. 2 and is an evening star at the end of the month. Venus is still a morning star. Mars is too near the sun for observation. Jupiter is a morning star in the constellation of Gemini. Saturn is a morning star north of Aldebaran. Occultations of stars brighter than magnitude 5 are as follows: Aug. 6d. 0lh. $41.9 \mathrm{~m}$., 71 Tauri, R.; Aug. 6d. 01h. 58.8m., $\theta^{2}$ Tauri, D. ; Aug. 6d. 02h. 09.8m., $\theta^{1}$ Tauri, D. ; Aug. 6d. 02h. 44.0m., $\theta^{1}$ Tauri, R. ; Aug. 6d. 02h. $54 \cdot 9 \mathrm{~m}$., $\theta^{2}$ Tauri, R.; Aug. 30d. 00h. 49.4m., v Piscium, R.

There will be a partial eclipse of the sun on Aug. 12, invisible at Greenwich. On Aug. 26 there will be a total eclipse of the moon, partly visible at Greenwich. The circumstances of the eclipse are as follows:

$\begin{array}{lcc}\text { Moon enters penumbra Aug. 26d. } 01 \mathrm{~h} . & 01 \cdot 7 \mathrm{~m} \\ \text { ", umbra } & 02 & 00 \cdot 5 \\ \text { Total eclipse begins } & 03 & 00 \cdot 9 \\ \text { Middle of eclipse } & 03 & 48 \cdot 0 \\ \text { Total eclipse ends } & 04 & 35 \cdot 0 \\ \text { Moon leaves umbra } & 05 & 35 \cdot 3 \\ \text { " ", penumbra } & 06 & 34 \cdot 0\end{array}$

The Perseid meteor shower will attain its maximum during Aug. 10-12.

\section{Announcements}

Prof. J. W. H. Eyre, emeritus professor of bacteriology, University of London, has been elected president of the Royal Institute of Public Health and Hygiene in succession to the late Sir Thomas Oliver. Prof. Eyre was senior vice-president and one of the founders in 1903 of the Institute of Hygiene, which amalgamated in 1937 with the Royal Institute of Public Health to form the present Institute.

AT a meeting of the Yorkshire Federation of Museums and Art Galleries, recently held at Huddersfield, Mr. T. Sheppard, formerly director of the Museums at Hull, was elected an honorary life member, "in recognition of his services to the International museum movement, and to the Yorkshire Federation in particular"

The following appointments have been made in the Agricultural Department of the University of Leeds : Mr. J. B. Mackinson, honorary assistant to the Veterinary Investigation Officer; Mr. P. H. Brown, lecturer in horticulture; Miss E. M. Parker, assistant lecturer in agricultural bacteriology; Miss Margaret W. Crunan, instructor in rural domestic economy; Miss Elizabeth Darley, temporary instructor in poultry husbandry. 